\title{
RE-MAPPING THE RIVER ON FILM
}

\author{
By Vanessa Lamb
}

Working in Southeast Asia as an academic and as a staff member for an environmental organization, I have witnessed non-fiction film being increasingly used for environmental advocacy and awareness-building, especially in the context of hydropower development. Such films seek to highlight the threats posed by hydropower to rivers and to the local residents who depend on them. However, my experiences with some of these films brring to light the degree to which the films themselves re-assert or produce specific claims about particular places and about development. As a geographer, I want to explore the cartographic possibilities and pitfalls of activist film projects.

What cartographic stories does film tell? Are films, like maps, constitutive of technologies of power? As non-fiction film has been increasingly produced for environmental causes worldwide, I believe that "film-as-map" deserves interrogation. Accordingly, film is examined here as a medium through which non-governmental organizations (NGOs), activists and local residents collaboratively stake claims, construct boundaries and effectually re-map the river. I want to explore what ways film can offer marginalized groups an avenue to push for change or resistance against unjust development schemes (similar to countermapping strategies). Also, what are the disadvantages of using such strategies and how can film benefit from critiques and analysis from within the discipline of geography?

The case studies I draw on are from my work in Southeast Asia, where the Mekong and Salween rivers have re-emerged both as the focus of increasingly heated debates surrounding contested claims, and as sites of potential hydropower development, bringing a range of local and non-local actors to negotiate and compete for a valuable resource - water. The two films I examine here are Salween: A River of Ethnic Minorities produced by the 
Living River Siam, formerly Southeast Asia Rivers Network (SEARIN), a Thai based NGO, and Damming the Yin Ta Lai produced by the Karenni Research Development Group, a Thaibased NGO focusing on issues related to the Karenni people.

As the latter film explains, the Yin Ta Lai is a sub-group of the Karenni people who live along the Salween River. Damming the Yin Ta Lai is premised upon their untold story as narrated by a young community member. He urgently explains that, "If the new dams go forward, all of our villages and land will be flooded. Our free flowing river will become a lake. Our way of life and everything we have will disappear. The Yin Ta Lai will be no more." The film narrates a history and customs of the Yin Ta Lai and connects their livelihood and cultural practices to the river and other local resources. Similarly, Salween: A River of Ethnic Minorities highlights the livelihood and cultural practices of multiple ethnic groups, including those residing in Thailand, Burma, China, and Tibet. This film also illustrates the connection of local residents to the river, for instance in place names, and documents other locally established ways of knowing. That these films incorporate both oral (versus written) documentation of everyday practices, images, and that they are also a collaborative work between local residents and NGOs are important points to which I return.

\section{Maps \& territory: territory as an analytical lens}

In this analysis, I focus on territory as an analytical lens that includes claims to space and place, knowledge, and power over a geographic area. Specifically within Southeast Asia, Vandergeest and Peluso argue that, territorialization is "about excluding or including people within particular geographic boundaries, and about controlling what people do and their access to natural resources within those boundaries" (388). They call attention to "the state's ignorance of local claims," which contributes to the increased ambiguity and contestation with regard to boundaries of land and resource use, much more so than map-makers and state 
land planners take into account (415). In effect, lived realities run counter to the neat and clean boundaries espoused by state land titling, national park boundary drawing, etc. This slows and complicates state efforts to claim property. Such a critique opens space for an understanding of how fluid, dynamic media such as film could be well-suited to illustrate the lived cartographies of local residents and as a point for resistance.

Both territory-making and map-making are intertwined processes. Some of the ways that territory has been conventionally produced is through conventional technologies of knowing, particularly mapping. Thongchai, noted Thai historian, shows us how the mapping of Siam (present-day Thailand) articulated specificities of the colonial moment. He also shows us how mapping and territorialization are intertwined strategies, focusing on the power in mapping as part of the production of territory. Thongchai writes, "The hegemony of modern geography, mapping, and the geo-body of a nation is far stronger than perhaps we are prepared to realize... This is not only true of the Thai people; it extends to many other cases in this mapped world" (xi).

However, while Thongchai's sentiments may seem to express that we are to be subsumed under a geographic regime, many other scholars have brought to light how locally derived technologies of knowing and mapping can at the same time present challenges (and alternative strategies) to conventional state-derived notions of territory. Vandergeest and Peluso note that people's "disruption of territorial strategies by non-compliance or open resistance has helped render territorial control, which is simple and efficient on paper, complex and inefficient in practice" (416). Separately, Peluso also investigates countermapping by NGO activists as a strategy in Indonesian forest management conflict. "[A]n alternative or 'counter' mapping movement has begun," she writes. "Local activists, with international and sometimes government assistance of various sorts, are using sketch maps to 
delineate and formalize claims to forest territories and resources their villages have traditionally managed" (384).

Peluso also suggests that "The practical effect is far-reaching: the use of maps and a highly 'territorialized' strategy redefines and reinvents customary claims to standing forest resources and harvestable products as claims to the land itself" (384). Moreover, Peluso raises questions regarding "the control of power when NGOs and other local groups utilize high technology empowerment strategies" (384). Here, Peluso and more recently Roth call attention to the power dynamics involved in and implications of counter or community-based map production, such as rendering dynamic, shifting processes static.

\section{Non-fiction film as counter-mapping strategy?}

Here, I consider the production of non-fiction advocacy and awareness-raising films as a counter-mapping and counter-territorialization strategy. I explicitly examine territory as an "enactment" that requires a "continual, active "doing"” which in turn focuses on "persuasion" or communication of claims to others (Blomley 122). I also build on academic work in geography that has examined nature as a construction- through images and other artifacts (i.e., Braun). ${ }^{1}$

\section{Local knowledge production and claim-making}

Both of the films I draw on - Salween: A River of Ethnic Minorities and Damming the Yin Ta Lai - focus on the stretch of the Salween River located at the border between Thailand and Burma. At present, the Salween is boasted as being the longest free-flowing river in Southeast Asia. It is also the focus of several large hydropower development projects. Connected directly to these impending developments, "local" knowledges used throughout

\footnotetext{
${ }^{1}$ At different points in my analysis, I also referenced feminist geographer Gillian Rose's book, Visual Methodologies.
} 
these films serve to challenge specialized or privileged knowledges of the expert and simultaneously, to make claims to knowing space and place. ${ }^{2}$ This runs in contrast to a conventional process of hydropower development in Southeast Asia and elsewhere, where the expert is called upon in multiple ways, long before the dam is built. For instance, studies are performed by both regional and international experts on fish migrations and patterns. Also, anthropologists and linguists are in many instances used to verify or reject claims regarding indigeneity, culture, and migration of people. Conservation biologists and international conservation organizations identify species of conservation concern (i.e., endangered) and have, in some cases, identified "safe" areas to impose reservoirs (King et al.).

Examples of local knowledge that appear in both films include fish species counts done by local residents and fishermen. These claims also highlight the importance of a freeflowing river and run in contrast to, for instance, using fish species counts done by fisheries biologists or conservation groups. Also, by highlighting livelihood activities and their connections to the river, the importance of local technologies such as agricultural techniques and fishing gears are clearly recorded in the films. Moreover, the portrayal in both films of the role of resident communities in the naming of rivers and sites along the Salween further make clear the claims (and highlight the validity of such claims) through historical use, ethnic, ancestral connections as well as the connection to/influence on modern state ways of knowing and naming.

One specific example that I choose to highlight here is the construction of the river's name - Salween. Salween: A River of Ethnic Minorities details different names for this river. In Yunnan province of China, for instance, it is called "angry river" due to the large amount

\footnotetext{
${ }^{2}$ By using the term local knowledge, I am emphasizing its locally grounded connection. However, as part of the debate between what constitutes local knowledge and Knowledge, I recognize that all knowledges are situated, partial, and incomplete (Haraway 1988).
} 
of rapids, as compared to the area of the Yin Ta Lai where it is called "Kong". The film explains that the now conventional name Salween actually is a corrupt version of the Burmese language word "Thalwin" which the British appropriated as "Salween".

These locally informed knowledges are indeed claim-making strategies. Scholars have shown how conventional knowledge production around development schemes is an exercise in claim-making and how much it leaves resident communities (ethnic minorities or not) out of, at the margins, or as that target of improvement schemes (Li 2007, Goldman 2004, Ferguson 1990). By re-asserting place- and/or ethnic group-specific names and ways of knowing, the film maps and renders legitimate these names in the context of local people who have legitimate control over this space and resource.

I also want draw out the film's focus on ethnic identities. For instance, both film titles invoke and reflect the importance of ethnicity or ethnic identities. These identities are also constructed and re-made throughout the films' images and narratives. Even along the small portion of the Salween that makes up the Thai-Burma border, several ethnic groups reside; one group - the Yin Ta Lai - is known to have no more than one thousand members remaining and is indeed in direct threat of being displaced by the reservoir of a cascade of dams planned along the Thai-Burma border. In the context of contested land claims or displacement, ethnic or indigenous identities are invoked as connected to both claims to knowledge and to land.

\section{Legitimacy of local use rights}

Through these two films, claims are also made to space and place through concepts of resource use and belonging. Riverbank gardening, for instance, is a locally practiced form of vegetable growing that relies on the nutrient rich sediment left on the riverbanks during 
seasonally low water levels; this is included as an essential livelihood practice. Fishing - in boats, along banks and in pools by both women and men, depending on season - is featured prominently in images and narrative. Images of rice cultivation, both wet and dry, are shown in addition to swidden agricultural activities. These images portray the shifting, dynamic nature of resources use (such as swidden) and again position local knowledges and technologies as an integral part of the riverscape. Moreover, these dynamic notions of resource use (such as daily cross border movement as connected to resource use) challenge state-centric, static mappings of, for instance, the river as a border or site of exclusion between states.

These films also paint a picture of what is and should be seen as part of the riverscape, highlighting who has access as well as proper use and control to that access. The images as chosen are testament to the NGO and activist control over the type and content of images that are "allowed" to represent the river; part of a strategy of counter-mapping. These images are shown in contrast to the Thai or Burmese state's claims to the Salween River for hydropower development, which are fraught with a legacy of displacement and intimidation. Hydropower development would displace ethnic peoples and their ways of knowing; in these films this move is seen as an illegitimate threat to river, creating a counter narrative which can be used to support claims, assert power and mobilize resistance.

The way in which these films communicate their content not only visually but orally by local residents is also of note. As Scott has emphasized, hill-tribe groups in Southeast Asia have traditions of oral histories. By using and emphasizing oral tradition as orated by local residents - in the films' interviews and in the main narrative - these films challenge written histories. Written histories have often detailed and developed claims to place and ethnicity from an institutional perspective, such as the state or the monarchy. Indeed, geographers and 
scholars of territory such as Moore have argued against "the privileging of institutional sociologies and histories" (5) and a focus on power as solely within the state (21). In contrast, Moore explains that "micropractices matter" (12) and also emphasizes the importance of contingent and relational histories in the production of place (18). By explaining what resettlement has done to local people, how compensation has been withheld, and how violence continues, especially in Burma, these oral histories and accompanying images of violence frame dams as a threat to humanity and the residents' future; not as a mechanism for development, progress, or improvement. These histories also connect the state with dams and violence, again highlighting the state's illegitimate claims to land and river. As part of the process of territory-making, these films are at once challenging conventional notions of territory construction, in part making space for a counter- or re-territorialization of the river, while also constructing specific ancestral claims to land through oral histories.

\section{End points \& points for consideration in future research}

Throughout this analysis I have focused on examples of territory as a process something done, made, performed, and communicated - which includes claims to space and place, knowledge, and power over geographic area. Non-fiction films exemplify the ways that territorial claims are made and mapped by NGOs, activists and local residents to each other and a larger audience. Through film, these groups exert control over the type and content of images that are allowed or chosen to represent the river: painting a particular picture of what is or should be seen as part of the riverscape, highlighting who has access, and demonstrating the proper use and control of the resources from the perspective of these groups. For all of these reasons, I contend that these films represent a strategy of countermapping that offers both opportunities and contradictions for participating communities. 
By examining film as an exercise of knowledges, boundaries and power, we can understand how these actions reflect the complex entanglements of the process of territory production. These films do have weaknesses, nonetheless, and they risk adopting the sort of "cartographic baggage" that Peluso and Roth identified in counter-mapping, such as fixing in space and in narrative processes that are and need to be dynamic. For example, by embodying "romantic" ideals of indigenous peoples and nature, the films could be critiqued as part of a larger, global discourse that essentializes identities or fixes local people in time and place. At the same time, by not including some of the contradictory voices - such as the state or developers - in interviews or other ways, the films' narratives could serve to reify a static relationship with the state. While this may certainly reflect local realities and relationships, it could also serve as an important point for both further negotiations and for further documentation, and at the very least, deserves explanation.

At the same time though, non-fiction film has been part of a strategic move and collaborative effort between resident communities, fishermen and others who participated in the filming and the NGOs and activists who produced these films. This collaboration has produced new synergies and furthers an alternative production of the river and hydropower development. ${ }^{3}$ Non-fiction films could also be seen as increasing the space for discussion, and as introducing new or counter discourses. I would assert that the fact that these films are available to a broad audience - on-line and in many languages, as well as being available locally in many villages - underlines the films' potential effects as a communication format that can reach a variety of audiences. ${ }^{4}$

\footnotetext{
${ }^{3}$ I draw on Anna Tsing's conceptualization of collaboration (Tsing 161).

${ }^{4}$ I am also very much interested in the ways daily discourses, practices and performances affect the way people see or relate to the river. I believe that these articulations of power, control, and ways of knowing have material implications. I am curious to understand how or if local perceptions of the river and material use differed before and after individuals were informed of the hydropower projects by NGOs and activists.
} 
Certainly, non-fiction film production is not the only technology through which claims are made by NGOs, activists and local residents, but it is one of the many constructions of knowing and witnessing the river. As a tool of power and resistance, it constitutes one aspect to examine as part of a move towards new critical examinations and understandings of locally derived geographies of territory.

\section{Works Cited}

Blomley, Nicholas. "Law, Property, and the Geography of Violence: The Frontier, the Survey, and the Grid." Annals of the Association of American Geographers 93.1 (2003): 121-141.

Braun, Bruce. The Intemperate Rainforest: Nature, Culture, and Power on Canada's West Coast. Minneapolis: University of Minnesota Press, 2002.

Damning the Yin Ta Lai. Karenni Development Research Group. Salweenwatch.org, 2008. Last accessed Sept 2008 at http://www.salweenwatch.org.

Delaney, David. Territory: a short introduction. Malden, MA: Blackwell Publishing, 2005.

Ferguson, James. The Anti-Politics Machine: "Development," Depoliticization, and Bureaucratic Power in Lesotho. Cambridge, New York: Cambridge University Press, 1990.

Goldman, Michael. "Imperial Science, Imperial Nature: Environmental Knowledge for the World (Bank)." Earthly Politics: Local and Global in Environmental Governance. Eds. Sheila Jasanoff and Marybeth Long Martello. Cambridge, MA: MIT Press, 2004.

Haraway, Donna. "Situated Knowledges: The Science Question in Feminism and the Privilege of Partial Perspective." Feminist Studies, 14.3 (Fall 1988): 575-599.

King, Peter., Jeremy Bird, and Lawrence Haas. Environmental Criteria for Hydropower Development in the Mekong Region. Vientiane, Laos: World Wildlife Fund, 2007.

Li, Tania. The Will to Improve: Governmentality, Development, and the Practice of Politics. Durham: Duke University Press, 2007.

Moore, Donald. S. Suffering For Territory: Race, Place and Power in Zimbabwe. Durham: Duke University Press, 2005.

Peluso, Nancy. "Whose Woods Are These? Counter-mapping Forest Territories in Kalimantan, Indonesia." Antipode 27.4 (1995): 383-406. 
Rose, Gillian. Visual methodologies: An Introduction to the Interpretation of Visual Materials. Thousand Oaks: Sage, 2001.

Roth, Robin. "Two-dimensional Maps in Multi-dimensional Worlds: A Case of Communitybased Mapping in Northern Thailand." Geoforum 38.1 (2007): 49-59.

Salween: A River of Ethnic Minorities. Living River Siam. Chiang Mai: 2007. Last accessed Sept 2008 at www.livingriversiam.org/salween_en.htm.

Scott, James C. “'Zomia': Site of the Last Great Enclosure Movement of (relatively) State-less Peoples in Mountainous Southeast Asia." University of Toronto Seminar Series presentation, 9 Oct 2008.

Sundberg, Juanita. "Identities in the Making: Conservation, Gender, and Race in Maya Biosphere Reserve, Guatemala." Gender, Place, and Culture 11.1 (2004): 43-66.

Thongchai Winichakul. Siam Mapped: A History of the Geo-body of a Nation. Honolulu: University of Hawaii Press, 1994.

Tsing, Anna Lowenahupt. Friction: An Ethnography of Global Connection. Princeton, NJ: Princeton University Press, 2005.

Vandergeest, P. and N. Peluso. "Territorialization and State Power in Thailand." Theory and Society 24.3 (1995): 385-426. 